\title{
Hubungan Asupan Energi Sarapan terhadap Tingkat Konsentrasi pada Siswa-Siswi Kelas XII SMA Negeri 1 Padang Tahun Ajaran 2013/2014
}

\author{
Kurnia Maidarmi Handayani ${ }^{1}$, Masrul $^{2}$, Adrial $^{3}$
}

\begin{abstract}
Abstrak
Indonesia menduduki peringkat terakhir dalam cognitive skills dan pencapaian pendidikan menurut penelitian yang dilakukan oleh Economist Intelligence Unit. Cognitive skills memerlukan fungsi otak yang adekuat yang dipertahankan oleh nutrisi berupa konsumsi pangan yang baik dan beragam, terutama sarapan. Penelitian di Amerika Serikat pada anak usia sekolah remaja (15-18 tahun) menunjukkan bahwa sebesar $30 \%$ remaja tidak biasa sarapan. Penelitian ini bertujuan untuk mengetahui hubungan antara asupan energi sarapan dan tingkat konsentrasi pada siswa SMAN 1 Padang. Studi dilakukan di SMAN 1 Padang pada bulan November 2013 terhadap 116 siswa kelas XII. Desain penelitian bersifat analitik dengan desain cross sectional. Pengolahan data dilakukan dengan uji chi-square menggunakan sistem komputerisasi. Hasil penelitian menunjukkan terdapat perbedaan tingkat konsentrasi menggunakan digit symbol test antara siswa dengan asupan energi sarapan baik, kurang, dan sangat kurang $(p=0,001)$ dan tidak terdapat perbedaan tingkat konsentrasi menggunakan digit span test antara siswa dengan asupan energi sarapan baik, kurang, dan sangat kurang $(p=0,345)$. Terdapat hubungan yang bermakna antara asupan energi sarapan dengan tingkat konsentrasi menggunakan digit symbol test $(\mathrm{p}<0,05)$.
\end{abstract}

Kata kunci: sarapan, asupan energi, konsentrasi, digit symbol test, digit span test

\section{Abstract}

Indonesia was ranked last in the cognitive skills and educational attainment according to research conducted by the Economist Intelligence Unit.Cognitive skills require brain function is maintained by adequate intake of nutrients such as good and varied food, especially breakfast. Research in the United States in children of school age youth (1518 years) showed that $30 \%$ of teenagers are not usually did breakfast. This study aimed to determine the relationship between energy intake at breakfast and the level of concentration of students of SMAN 1 Padang. The study was conducted at SMAN 1 Padang in November 2013 to 116 students of class XII. The research was an analytical study with cross-sectional design.Data processing is performed by the chi-square test using a computerized system. The results showed there were differences in the level of concentration using the digit symbol test between students with a good breakfast energy intake,less, and much less $(p=0.001)$ and there was no difference in the level of concentration using the digit span test between students with a good breakfast energy intake, less, and very less $(p=0.345)$. There is a significant relationship between breakfast energy intake with the level of concentration using digit symbol test $(p<$ 0.05).

Keywords: breakfast, energy intake, concentration, digit symbol test, digit span test

Affiliasi penulis : 1. Pendidikan Dokter FK UNAND (Fakultas Kedokteran Universitas Andalas Padang), 2. Bagian IImu Gizi FK UNAND, 3. Bagian Parasitologi FK UNAND

Korespondensi :Kurnia Maidarmi Handayani,email:

niamh_pd@yahoo.com, Telp: 085263626564

\section{PENDAHULUAN \\ Indonesia menduduki peringkat terakhir} dalam hal cognitive skills dan pencapaian pendidikan menurut penelitian yang dilakukan oleh Economist 
Intelligence Unit pada 39 negara dan satu wilayah (Hongkong) di seluruh dunia. Hal ini menunjukkan kemampuan kognitif siswa-siswi di Indonesia masih memerlukan perhatian khusus. Cognitive skills merupakan kemampuan otak untuk mendapatkan pengetahuan dan pemahaman dari suatu pengalaman dan informasi, hal ini memerlukan fungsi otak yang adekuat yang dipertahankan oleh nutrisi dengan cara menjamin ketersediaan neurotransmitter. Nutrisi yang adekuat dapat tercapai apabila didukung dengan konsumsi pangan yang baik dan beragam, terutama sarapan. $^{1-5}$

Hasil penelitian di Amerika Serikat pada anak usia sekolah remaja (15-18 tahun) menunjukkan bahwa sebesar 30\% remaja tidak biasa sarapan. Muchtar, dkk. melakukan penelitian pada tahun 2011 di SMA N 1 Pahadut Palangkaraya menemukan sekitar 37,7\%-38,8\% siswa di sekolah tersebut tidak sarapan. Penelitian lain juga membuktikan bahwa makan pagi berpengaruh pada konsentrasi dan prestasi belajar anak sekolah. Hasil penelitian di Israel menunjukkan kelompok anak yang sarapan memiliki hasil test daya ingat yang lebih baik dibandingkan kelompok yang tidak sarapan. Muchtar, dkk. juga melakukan penelitian pada siswa sekolah menengah atas di Palangka Raya tahun 2011 menggunakan metode digit symbol test dan digit span test yang menunjukkan ada perbedaan kemampuan konsentrasi remaja yang sarapan secara bermakna dibandingkan kelompok remaja yang tidak sarapan. ${ }^{5,6}$

SMAN 1 Padang merupakan salah satu sekolah menengah negeri unggulan yang siswanya memiliki kemampuan kognitif yang baik. Hal ini dibuktikan dengan nilai rata-rata UN tahun 2013 seSumatera Barat tertinggi diraih oleh SMAN 1 Padang, yaitu 51,17. Penelitian ini dilakukan untuk mengetahui hubungan asupan energi sarapan terhadap tingkat konsentrasi pada siswa-siswi SMAN 1 Padang.

\section{METODE}

Penelitian ini dilakukandi SMAN 1 Padang pada bulan Juni - November 2013 dengan menggunakan116 siswa. Siswa tersebut merupakan siswa-siswi kelas XII yang telah berumur 16 tahun dan bersedia untuk berpartisipasi dalam penelitian, serta tidak dalam keadaan sakit, tidak berpuasa, dan tidak dalam keadaaan stress menurut skala Holmes dengan menggunakan teknik total sampling.

Penelitian ini bersifat analitik dengan desain cross sectional. Pengolahan data dilakukan dengan uji chisquare menggunakan sistem komputerisasi. Variabel independen adalah asupan energi sarapan dan variabel dependen adalah tingkat konsentrasi yang diuji menggunakan digit symbol test dan digit span test.

HASIL

Subyek merupakan siswa kelas XII SMA Negeri 1 Padang yang memenuhi syarat inklusi dan hadir saat penelitian. Berdasarkan penelitian tersebut didapatkan karakteristik berupa umur, jenis kelamin, kebiasaan sarapan, jumlah asupan dan gambaran konsentrasi subyek.

Tabel 1. Distribusi Subyek Berdasarkan Umur Dan Jenis Kelamin

\begin{tabular}{llllllll}
\hline \multirow{2}{*}{$\begin{array}{c}\text { Umur } \\
\text { (tahun) }\end{array}$} & \multicolumn{4}{c}{ Laki-laki } & \multicolumn{2}{c}{ Perempuan } & \multicolumn{2}{c}{ Total } \\
\cline { 2 - 6 } & \multicolumn{1}{c}{ f } & \multicolumn{2}{c}{$\%$} & \multicolumn{1}{c}{$\mathbf{f}$} & $\%$ & $\mathbf{F}$ & \multicolumn{1}{c}{$\%$} \\
\hline 16 & 3 & 2,6 & 7 & 6 & 10 & 8,6 \\
17 & 34 & 29,3 & 65 & 56 & 99 & 85,3 \\
18 & 6 & 5,2 & 1 & 0,9 & 7 & 6 \\
\hline Total & 43 & 37,1 & 73 & 62,9 & 116 & 100 \\
\hline
\end{tabular}

Keterangan: $\bar{X}$ umur $=16,9(\mathrm{SD} \pm 0,3)$ tahun

Berdasarkan tabel 1 dapat dilihat bahwa lebih dari setengah subyek merupakan siswa perempuan dengan rerata umur 16,9 (SD $\pm 0,3)$ tahun.

Tabel 2. Distribusi Kegiatan Sarapan Subyek

\begin{tabular}{cccc}
\hline Kegiatan Sarapan & $\mathbf{f}$ & $\%$ & Total \\
\hline Kebiasaan Sarapan & 49 & 42,2 & \\
Selalu & 28 & 24,1 & 116 \\
Sering & 33 & 28,4 & \\
Jarang & 6 & 5,2 & \\
Tidak Pernah & & & \\
Kegiatan Sarapan saat Penelitian & & & \\
Sarapan & 89 & 76,7 & 116 \\
Tidak Sarapan & 27 & 23,3 & \\
\hline
\end{tabular}

Berdasarkan tabel 2 dapat dilihat bahwa sekitar sepertiga siswa jarang sarapan (28,4\%) dan $5,2 \%$ tidak pernah sarapan dan pada saat penelitian dilakukan $23,3 \%$ siswa tidak sarapan. 
Tabel 3. Gambaran Asupan Energi Sarapan dan Konsentrasi Subyek

\begin{tabular}{llll}
\hline & Rerata/Median & Min & Maks \\
\hline $\begin{array}{l}\text { Jumlah Asupan Energi } \\
\text { Sarapan (Kalori) }\end{array}$ & 423,3 & 54,8 & 1592 \\
Skor Digit Symbol Test & $43,7(\mathrm{SD} \pm 13,4)$ & 16,5 & 67 \\
Skor Digit Span Test & $14,5(\mathrm{SD} \pm 4,1)$ & 5 & 24 \\
\hline
\end{tabular}

Berdasarkan tabel 3 dapat diketahui bahwa dari total 89 subyek yang sarapan, jumlah asupan energi minimum adalah 54,8 kalori, jumlah asupan energi maksimum adalah 1592 kalori sehingga didapatkan median asupan energi sarapan sebanyak 423,3 kalori. Berdasarkan tabel 3 juga dapat diketahui bahwa skor terendah dari Digit Symbol Test pada subyek adalah 16,5, sedangkan skor tertinggi adalah 67. Dari tabel tersebut dapat juga diketahui skor rerata yang didapatkan subyek adalah 43,7 (SD $\pm 13,4)$. Dari tabel diatas juga dapat diketahui skor terendah untuk Digit Span Test pada subyek adalah 5 dan skor tertinggi adalah 24 dengan rerata skor sebesar 14.5 $(\mathrm{SD} \pm 4,1)$.

Tabel 4. Hubungan Asupan Energi Sarapan terhadap Tingkat Konsentrasi Subyek

\begin{tabular}{|c|c|c|c|c|c|}
\hline \multirow{2}{*}{$\begin{array}{c}\text { Tingkat } \\
\text { Konsentrasi }\end{array}$} & \multicolumn{3}{|c|}{ Asupan Energi Sarapan } & \multirow[b]{2}{*}{ Jumlah } & \multirow[b]{2}{*}{$\mathbf{P}$} \\
\hline & Baik & Kurang & $\begin{array}{l}\text { Sangat } \\
\text { Kurang }\end{array}$ & & \\
\hline Digit Symbol & & & & & \\
\hline \multicolumn{6}{|l|}{ Test } \\
\hline Tinggi & 20 & 19 & 10 & 49 & 0,001 \\
\hline Rendah & 8 & 42 & 17 & 67 & \\
\hline \multicolumn{6}{|l|}{ Digit Span Test } \\
\hline Tinggi & 17 & 27 & 14 & 58 & \multirow{3}{*}{0,345} \\
\hline Rendah & 11 & 34 & 13 & 58 & \\
\hline Jumlah & 28 & 61 & 27 & 116 & \\
\hline
\end{tabular}

Berdasarkan tabel 4 dapat dilihat pada digit symbol test subyek dengan asupan energi sarapan yang baik lebih banyak memiliki tingkat konsentrasi yang tinggi dibandingkan tingkat konsentrasi rendah. Hasil uji statistik menunjukkan perbedaan ini memiliki makna $(p<0,05)$. Dari tabel tersebut juga tampak pada digit span test subyek dengan asupan energi sarapan baik lebih banyak memiliki tingkat konsentrasi tinggi dibandingkan tingkat konsentrasi rendah. Namun, perbedaan tersebut secara statistik tidak bermakna ( $p$ $>0,05)$.

\section{PEMBAHASAN}

Pada tabel 1 dapat dilihat bahwa subyek berada paling banyak pada usia 17 tahun (85,3\%) dengan jenis kelamin perempuan lebih banyak $(62,9 \%)$, sedangkan tabel 2 dapat dilihat pula bahwa hari penelitian dilaksanakan sebanyak 27 siswa $(23,3 \%)$ tidak sarapan. Muchtar, dkk. juga telah melakukan penelitian di SMAN 1 Palangkaraya, menemukan bahwa sekitar 37,7\%-38,8\% siswa di sekolah tersebut tidak sarapan. Presentase ini lebih besar jika dibandingkan dengan penelitian ini. ${ }^{5}$

Jumlah asupan energi sarapan subyek yang tampak pada tabel 2 berkisar antara 54-1592 Kalori dengan nilai tengah 423,3 Kalori. Penelitian yang dilakukan oleh Muchtar, $d k k$. juga menunjukkan rerata jumlah asupan energi sarapan yang rendah, yaitu $255,6 \pm 113,85$ Kalori. Rerata skor digit symbol test siswa kelas XII SMAN 1 Padang adalah 43,7 $(S D \pm 13,4)$. Nilai ini lebih rendah dibandingkan dengan skor digit symbol test pada siswa SMAN 1 Palangkaraya, yaitu $55,8 \pm 7,03$. Rerata skor digit span test siswa kelas XII SMAN 1 Padang adalah 14,5 $(S D \pm 4,1)$, lebih tinggi dibandingkan dengan penelitian di SMAN 1 Palangkaraya, yaitu $7,1 \pm 1,68 .^{5}$

Jumlah siswa yang mengonsumi sarapan dengan jumlah energi sama atau lebih dari $25 \%$ kebutuhan energi harian atau dengan kategori baik adalah 28 siswa (24,1\%). Sementara itu, lebih dari setengah siswa (52,6\%) termasuk kedalam kategori asupan energi sarapan kurang, yaitu jumlah asupan energi sarapannya tidak mencapai $25 \%$ dari total kebutuhan energi harian.

Uji konsentrasi siswa menggunakan digit symbol test menunjukkan jumlah siswa dengan skor dibawah rata-rata atau konsentrasi rendah adalah 67 siswa $(57,8 \%)$. Konsentrasi menggunakan digit span test menunjukkan jumlah siswa dengan konsentrasi tinggi dan rendah adalah sama. Secara keseluruhan tingkat konsentrasi siswa SMAN 1 Padang berimbang antara konsentrasi tinggi dan konsentrasi rendah.

Siswa yang memiliki tingkat konsentrasi tinggi menggunakan digit symbol test lebih banyak pada siswa dengan asupan energi sarapan baik (71,4\%) dibandingkan dengan asupan energi kurang (31.1\%), 
dan sangat kurang (37\%). Hasil analisis secara statistik menunjukkan bahwa terdapat hubungan yang bermakna antara asupan energi sarapan dengan tingkat konsentrasi menggunakan digit symbol test pada siswa kelas XII SMAN 1 Padang $(\mathrm{p}<0,05)$. Digit symbol test melibatkan integrasi dari proses neuropsikologis kompleks yang meliputi visual scanning, mental flexibility, sustained attention, kecepatan psikomotor, dan kecepatan pemrosesan informasi. Proses tersebut memerlukan kerja otak dengan asupan glukosa yang adekuat. Sarapan dapat menyediakan asupan energi yang siap untuk meningkatkan kadar glukosa. ${ }^{7,8}$

Hasil uji konsentrasi menggunakan digit span test juga menunjukkan bahwa siswa yang memiliki konsentrasi tinggi lebih banyak pada siswa dengan asupan energi sarapan baik $(60,7 \%)$ dibandingkan dengan asupan kurang (44,3\%) dan sangat kurang (51,9\%). Namun, secara statistik tidak terdapat hubungan yang bermakna antara asupan energi sarapan dengan tingkat konsentrasi siswa menggunakan digit span test pada siswa kelas XII SMAN 1 Padang $(p>0,05)$. Digit span test memerlukan perhatian dan encoding sehingga hal-hal yang dapat mengalihkan perhatian dapat memengaruhi proses ini. Hal-hal yang diduga mempengaruhi hasil test pada penelitian ini adalah kualitas audio yang kurang baik dan tidak terstandarisasi.

Penelitian ini memiliki beberapa keterbatasan, yaitu tidak memperhitungkan faktor kualitas audio pada digit span test dan pada perhitungan asupan energi sarapan tidak mengelompokkan asupan berdasarkan jenisnya (karbohidrat, lemak dan protein).

\section{KESIMPULAN}

Kesimpulan penelitian ini ialah jumlah siswa yang tidak sarapan masih cukup tinggi $(23,3 \%)$, jumlah siswa dengan asupan energi sarapan kategori baik masih rendah, jumlah siswa yang memiliki konsentrasi di bawah rata-rata menunjukkan angka yang tinggi, dan terdapat hubungan yang bermakna antara asupan energi sarapan terhadap tingkat konsentrasi.

\section{UCAPAN TERIMA KASIH}

Penelitian ini dapat berlangsung berkat dukungan dari Dra. Kuswadarni, SP. MSi., Psikolog. Bersama ini kami juga turut mengucapkan terima kasih kepada Kepala SMAN 1 Padang, seluruh guru dan staf SMAN 1 Padang, serta siswa kelas XII SMAN 1 Padang yang telah membantu dan mendukung penelitian ini.

\section{DAFTAR PUSTAKA}

1. Economist Intelligence Unit. The learning curve (diunduh 19 Mei 2013). Tersedia dari: URL: HYPERLINK http://www.thelearningcurve. pearson.com/content/download/bankname/comp onents/filename/FINALLearningCurve Final.pdf.

2. Michelon P. What is a cognitive ability/what are cognitive abilities and skills?. (diunduh 17 Juni 2013). Tersedia dari: URL: HYPERLINK http://www.sharpbrains.com/blog/2006/12/8/whatare-cognitive-abilities/.).

3. Bellisle F. Effect of diet on behaviour and cognition in children. British Journal of Nutrition. 2004;92:227-32.

4. Isaacs E, Oates J. Nutrition and cognition: assesing cognitive abilities in children and young people. European Journal of Nutrition. 2008;47(S3):4-24.

5. Muchtar M, Julia M, Gamayanti IL. Sarapan dan jajan berhubungan dengan kemampuan konsentrasi pada remaja. Jurnal Gizi Klinik Indonesia. 2011;8(1):28-35.

6. Groger M, Granthan S. Can the provision of breakfast benefits school performance?.Food and Nutrition Bulletin. 2005;26(2):144-58.

7. Elst, et al. The letter digit subtitution test: normative data for 1,858 healthy participant Aged 24-81 from the Maastricht Aging Study (MAAS): Influence of age, education, and sex. Journal of Clinical and Experiment Neuropsychology. 2006; 28:998-1009.

8. Khomsan A. Sarapan sehat. Dalam: Pangan dan Gizi untuk Kesehatan. Jakarta: PT Raja Grafindo Persada; 2004.hlm. 103-6. 